\title{
Synthesis of $\beta$-D-ribofuranosylbenzazoles using nitrile oxide addition chemistry
}

\author{
Iain A.S. Smellie and R. Michael Paton* \\ EaStCHEM, School of Chemistry, The University of Edinburgh, The King's Buildings, \\ West Mains Road, Edinburgh, EH9 3JJ, UK \\ E-mail: R.M.Paton@ed.ac.uk
}

DOI: http://dx.doi.org/10.3998/ark.5550190.0013.905

\begin{abstract}
A nitrile oxide based route to $2-\beta$-D-ribofuranosylbenzazoles has been developed. Tri- $O$ benzoyl- $\beta$-D-ribofuranosylformonitrile oxide (14) was generated from the corresponding carbaldoxime 16 by treatment with NCS/pyridine, followed by base-induced dehydrochlorination of the resulting hydroximoyl chloride. Reaction of the nitrile oxide with 1,2-diaminobenzene afforded 2-(tri- $O$-benzoyl- $\beta$-D-ribofuranosyl)benzimidazole (21), from which 2-( $\beta$-Dribofuranosyl)benzimidazole (22) was prepared by treatment with $\mathrm{Et}_{3} \mathrm{~N} / \mathrm{MeOH}$. 2-Aminophenol reacted similarly to yield 2-(tri- $O$-benzoyl- $\beta$-D-ribofuranosyl)benzoxazole (18). In the absence of a co-reactant dimerisation of the nitrile oxide afforded 3,4-di(tri- $O$-benzoyl- $\beta$-Dribofuranosyl)-1,2,5-oxadiazole-2-oxide (17). The carbaldoxime starting material 16 was prepared from tri- $O$-benzoyl- $\beta$-D-ribofuranosyl cyanide by reaction with semicarbazide to form the semicarbazone, followed by transimination with hydroxylamine.
\end{abstract}

Keywords: Nitrile oxides, benzimidazoles, benzoxazoles, $C$-glycosides, $C$-nucleosides

\section{Introduction}

Nucleoside analogues ( $C$-nucleosides) in which the ribose unit is attached to a carbon atom of a heterocycle have attracted much attention, both from a synthetic perspective and on account of their potential biological activities. ${ }^{1}$ Two general approaches have been employed for their synthesis: introduction of an intact heterocycle at the anomeric centre of the furanose, and creation of the heterocycle at that position, for example via cycloaddition reactions. Among the latter methods are the 1,3-dipolar cycloaddition reactions of furanosyl nitrile oxides. ${ }^{2-5}$ A key step in the preparation by Albrecht, Repke and Moffat of 3-( $\beta$-D-ribofuranosyl)isoxazole-5carboxamide (1) was the cycloaddition of nitrile oxide 2 to ethyl propiolate. ${ }^{2}$ The Kozikowski group used nitrile oxide - isoxazoline chemistry ${ }^{6}$ to synthesise various $C$-nucleoside analogues, 
e.g. the ribofuranosyl pyrazole 3 and the indole compound $4 ;, ;$ and the same method was used by Baraldi et al. for the pyridazinone 5. ${ }^{5}$ Whereas the cycloaddition reactions of nitrile oxides have been extensively used over many years for heterocycle synthesis, their 1,3-nucleophilic addition reactions have received less attention. ${ }^{7}$ We have, however, recently established that nitrile oxide addition chemistry can be used to prepare 2-pyranosylbenzazoles (benzimidazoles 6 , benzoxazoles 7, benzothiazoles 8), ${ }^{8}$ and we anticipated that a similar approach might be used for their furanosyl analogues, as outlined in Scheme 1.

Such furanosylbenzazoles show a range of useful biological activities. They are of interest as antiviral compounds, ${ }^{9,10}$ and have been identified as potential therapeutic agents for the treatment of diseases such as cystic fibrosis. ${ }^{11}$ In particular it has been reported that they show excellent agonist potency and selectivity for the $\mathrm{P}_{2} \mathrm{Y}_{2}$ receptor, and that they also have enhanced metabolic stability compared with $N$-linked analogues and the natural ligand ATP. ${ }^{11}$ Methods for their synthesis have included addition of 2-lithiated benzimidazoles/benzothiazoles to sugar lactones and deoxygenation of the resulting hemiacetals, ${ }^{12-14}$ and reaction of 2-substituted anilines with aldonic acids, ${ }^{11,15}$ and with acetimidates/thioacetimidates derived from furanosyl cyanides. $^{16}$ Forcing conditions were sometimes required, mixtures of isomers formed and overall yields were variable. Alternative approaches are therefore desirable, particularly for the benzoxazoles and benzimidazoles. We selected nitrile oxide addition chemistry as it had the potential to provide furanosyl benzimidazoles, benzoxazoles and benzothiazoles all from the same source.<smiles>NC(=O)c1cc([C@@H]2O[C@H](CO)[C@@H](O)[C@H]2O)no1</smiles><smiles></smiles>

4<smiles>[R20]CC1OC(C#[N+][O-])C([R])C1[R2]</smiles>

Scheme 1
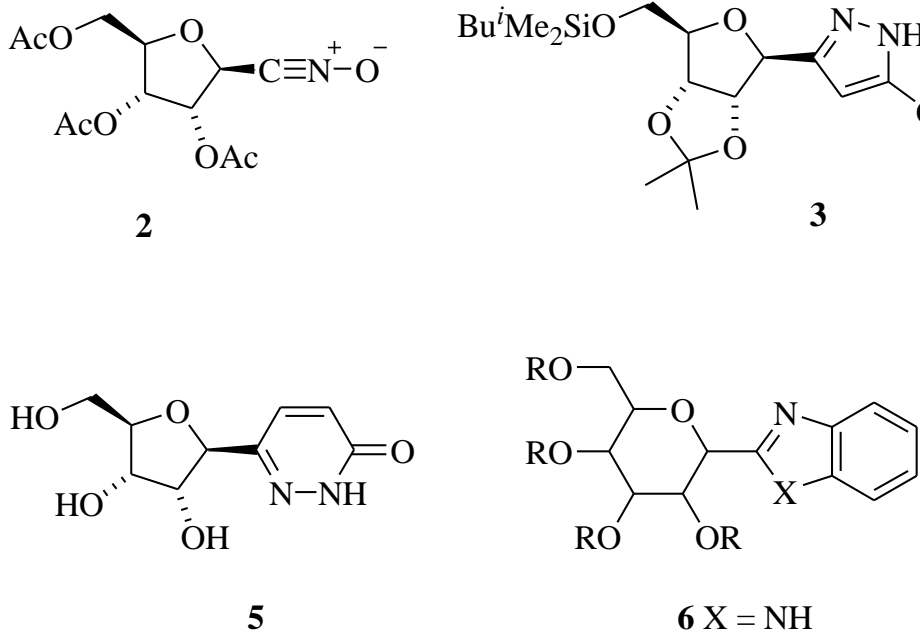

$6 \mathrm{X}=\mathrm{NH}$

$7 \mathrm{X}=\mathrm{O}$

$8 X=S$<smiles></smiles>

$\mathrm{X}=\mathrm{NH}, \mathrm{O}, \mathrm{S}$ 


\section{Results and Discussion}

In order to test the effectiveness of the method we selected the known $\beta$-D-ribose-derived nitrile oxide $\mathbf{1 4}^{2}$ as a representative example that should provide access to a range of benzazole $C$ nucleoside derivatives. As most nitrile oxides are short-lived compounds that readily dimerise to 1,2,5-oxadiazole $N$-oxides (furoxans), it is common practice in synthetic applications for the nitrile oxides to be generated in situ in the presence of the co-reactant. The two main methods, both of which have been used for carbohydrate synthesis, ${ }^{17}$ involve either base-induced dehydrohalogenation of hydroximoyl halides (usually the chloride) or dehydration of nitromethyl compounds. $^{6,18}$ In the present case the shortest route is conversion of D-ribose into the nitromethyl compound $\mathbf{1 1}$ via initial reaction condensation with nitromethane (the 'FischerSowden reaction'), followed by Mukaiyama-type dehydration of $\mathbf{1 1}$ with an isocyanate, e.g. $\mathrm{PhNCO}^{19}$ or tolylene diisocyanate. ${ }^{20}$ However, in our hands and those of others, ${ }^{21,22}$ the literature route to the nitromethylribose afforded a mixture of the $\alpha$ - and $\beta$-isomers which were time-consuming to separate and gave only a moderate yield of the target $\beta$-product. We therefore turned to the longer but ultimately more reliable route via the cyanide $\mathbf{9}$, the oxime $\mathbf{1 6}$ and the hydroximoyl chloride $\mathbf{1 5}$, as originally developed by the Moffat group. ${ }^{2}$

Of the various literature methods for the preparation of the starting material we chose that reported by Morelli et al., ${ }^{23}$ involving reaction of tri-O-benzoyl- $\beta$-D-ribofuranosyl acetate with trimethylsilyl cyanide in the presence of catalytic boron trifluoride etherate, and this afforded the cyanide 9 in $86 \%$ yield. As direct hydrolysis of 9 to the aldehyde 13, and thence the carbaldoxime 16, was reported to be problematic, the cyanide 9 was first converted into the imidazolidine derivative $\mathbf{1 0}(59 \%)$ by reaction with 1,2-dianilinoethane (Wanzlick's reagent) and sodium hypophosphite in acetic acid and pyridine. Treatment of the product with tosylic acid afforded the crude aldehyde $\mathbf{1 3}$, which was not isolated but reacted immediately with hydroxylamine-pyridine to afford the required aldoxime 16 (45\%). Although the oxime had thus been obtained by the Moffat group route, the procedure was not considered satisfactory for larger scale synthesis. Toth and Somsak have reported ${ }^{24}$ an alternative method which they used to convert pyranosyl cyanides into pyranosyl aldoximes via the corresponding semicarbazones, and we considered that this approach should also be applicable for their furanosyl counterparts. This proved to be the case. Reaction of the ribofuranosyl cyanide 9 with semicarbazide afforded the semicarbazone 12 (85\%), which was then converted to the aldoxime $16(81 \%)$ as a mixture of $E$ and $Z$-isomers by transimination with hydroxylamine. This latter route thus provided the oxime in $69 \%$ overall yield from the cyanide, compared with $27 \%$ via the imidazolidine. 


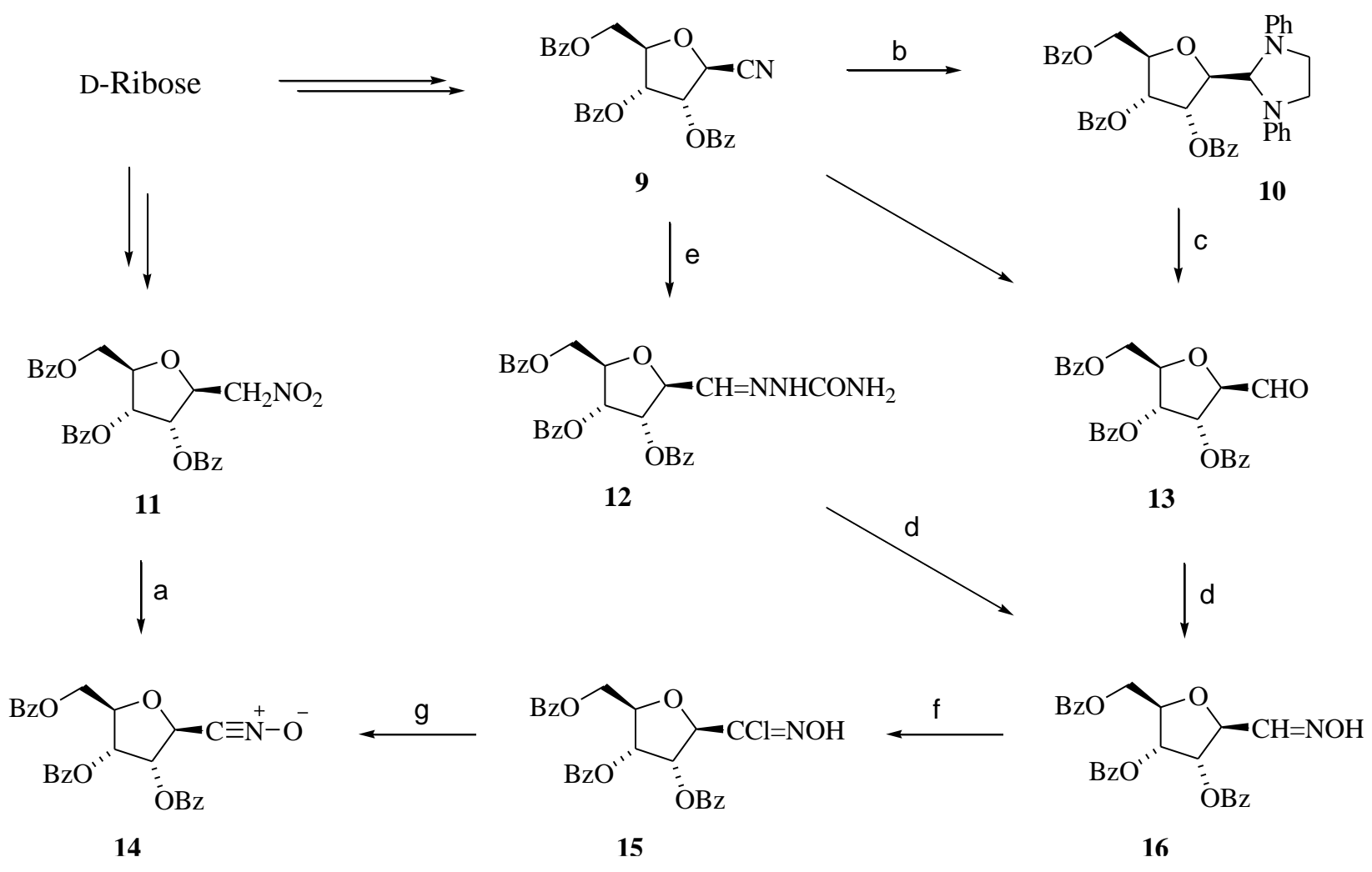

Scheme 2. Reagents: (a) RNCO, $\mathrm{Et}_{3} \mathrm{~N}$; (b) $\mathrm{PhNHCH}_{2} \mathrm{CH}_{2} \mathrm{NHPh}$, Raney $\mathrm{Ni}, \mathrm{NaH}_{2} \mathrm{PO}_{2} . \mathrm{H}_{2} \mathrm{O}$, pyridine, $\mathrm{AcOH}, \mathrm{H}_{2} \mathrm{O}$; (c) $\mathrm{TsOH}, \mathrm{H}_{2} \mathrm{O}, \mathrm{CH}_{2} \mathrm{Cl}_{2}$; (d) $\mathrm{NH}_{2} \mathrm{OH}$, pyridine; (e) $\mathrm{NH}_{2} \mathrm{NHCONH}_{2}$, Raney $\mathrm{Ni}, \mathrm{NaH}_{2} \mathrm{PO}_{2} . \mathrm{H}_{2} \mathrm{O}$, pyridine, $\mathrm{AcOH}, \mathrm{H}_{2} \mathrm{O}$; (f) $\mathrm{Cl}_{2}, \mathrm{Et}_{2} \mathrm{O}$ or $\mathrm{NCS}$, pyridine, $\mathrm{CHCl}_{3}$; (g) $\mathrm{Et}_{3} \mathrm{~N}$.

Attempts to convert the aldoxime 16 into the hydroximoyl chloride 15 with chlorine in diethyl ether, using the technique that we had previously used for pyranosyl hydroximoyl chlorides, ${ }^{25}$ were only partially successful and the product was not isolated in pure form. A milder chlorination procedure, originally reported by Larsen and Torssell, ${ }^{26}$ employing $N$ chlorosuccinimide in pyridine was therefore investigated. The hydroximoyl chloride was not isolated; instead the nitrile oxide was generated from the crude product by addition of triethylamine. The reaction was first carried out in the absence of a co-reactant in order to provide access to 3,4-di(tri- $O$-benzoyl- $\beta$-D-ribofuranosyl)furoxan (17) (72\%), which is of interest both in its own right and is also a likely by-product of reactions involving the nitrile oxide (Scheme 3). The product was identified from its spectroscopic properties. In the ${ }^{13} \mathrm{C}$ $\mathrm{NMR}$ spectrum in $\mathrm{CDCl}_{3}$ there are, in addition to the expected resonances for the two tri-Obenzoylribofuranose units, characteristic peaks at $112.6(\mathrm{C}-3)$ and $155.0 \mathrm{ppm}(\mathrm{C}-4)$ for the carbon atoms of the 1,2,5-oxadiazole ring. These values are typical for unstrained furoxans. ${ }^{27}$ In the proton NMR spectrum the two non-equivalent furanosyl substituents give rise to overlapping and only partially resolved signals. There are, however, distinct doublets at $5.46(\mathrm{H}-1)$ and 5.37 ppm (H-1') for the protons bonded to the carbons adjacent to $\mathrm{C}-3$ and $\mathrm{C}-4$, respectively, of the 
furoxan ring; these assignments were made by comparison with data reported for other dialkylfuroxans. ${ }^{28}$

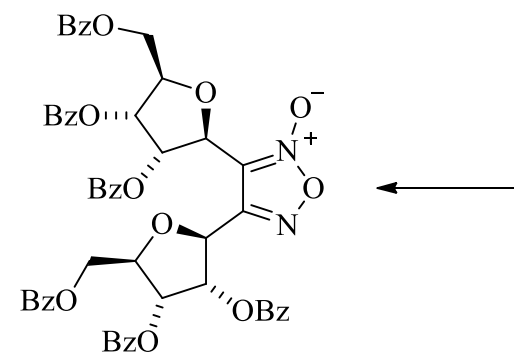

17

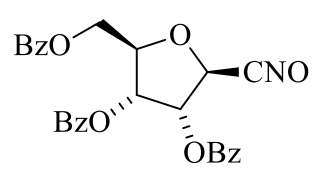

14

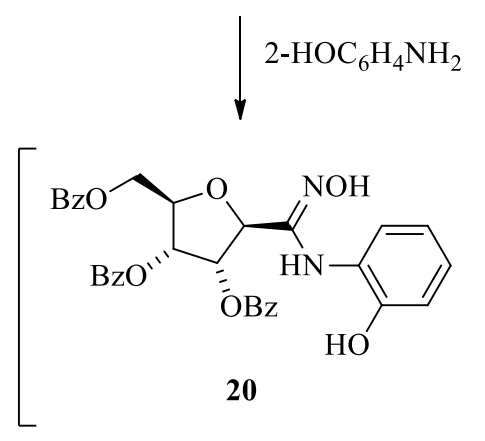

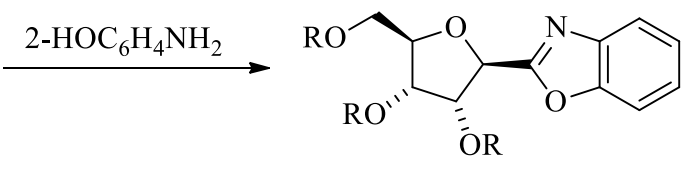

$18 \mathrm{R}=\mathrm{Bz}$

$19 \mathrm{R}=\mathrm{H}$
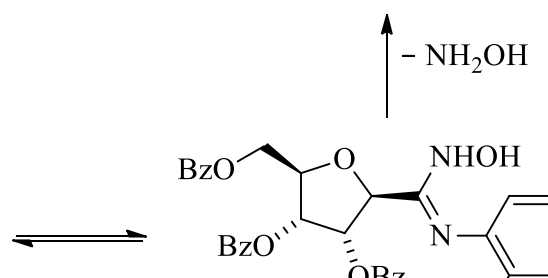

\section{Scheme 3}

Having isolated the furoxan $\mathbf{1 7}$ in good yield, and thus established that nitrile oxide $\mathbf{1 4}$ could be generated efficiently from the oxime $\mathbf{1 6}$ in a one-pot procedure, the synthesis of ribofuranosyl benzazoles was investigated. As an efficient route from glycosyl cyanides to glycosyl benzothiazoles is already well established, ${ }^{29}$ we concentrated our attention on the benzimidazoles and benzoxazoles. To obtain the benzoxazole 18 nitrile oxide 14 was reacted with 2aminophenol. A mixture of the oxime $16(0.30 \mathrm{mmol}), N$-chlorosuccinimide and pyridine in chloroform was heated at $40{ }^{\circ} \mathrm{C}$ for 45 minutes and, after cooling and removal of the solvent, 2aminophenol $(0.75 \mathrm{mmol})$ in ethanol was added and the solution heated at reflux for five hours. From the reaction mixture was isolated 2 -(tri- $O$-benzoyl- $\beta$-D-ribofuranosyl)benzoxazole (18) (90\%), which was identified from its spectroscopic properties. The carbon NMR spectrum in $\mathrm{CDCl}_{3}$ showed characteristic signals for the benzoxazole moiety [162.5 (C-2), 152.0 (C-7a), 141.7 (C-3a), 126.9 (C-5), 125.7 (C-6), 121.7 (C-4) and 112.0 ppm (C-7)], which were very similar to those previously reported for 2-pyranosylbenzoxazoles $\mathbf{7},{ }^{8}$ and are typical of 2-alkylsubstituted benzoxazoles. ${ }^{30}$ The presence of the perbenzoylribofuranose unit was evident in both the ${ }^{13} \mathrm{C}$ and ${ }^{1} \mathrm{H}$ NMR spectra. The reaction pathway is believed to proceed by initial dehydrochlorination of the hydroximoyl chloride 15 by one equivalent of the 2-aminophenol to generate the nitrile oxide 14, followed by nucleophilic addition of the anilino group of a second equivalent of 2-aminophenol to form the amidoxime 20; nucleophilic displacement of hydroxylamine by the phenolic group then leads to the benzoxazole, as illustrated in Scheme 3. 
Debenzoylation with $\mathrm{NaOMe} / \mathrm{MeOH}$ afforded the parent ribofuranosyl)benzoxazole 19 as a mixture of $\alpha$ - and $\beta$-anomers.

The approach used to prepare the ribofuranosylbenzimidazole was similar to that described above for the benzoxazole, but using 1,2-diaminobenzene (DAB) instead of 2-aminophenol as the nucleophilic co-reactant. Reaction of the nitrile oxide 14 with DAB (1:2.5 molar ratio) in ethanol at reflux for five hours afforded, after work-up, the per-benzoylated $\beta$-D-ribofuranosylbenzimidazole 21 in $92 \%$ yield. Work-up of the reaction mixture was aided by washing with $4 \%$ aq. $\mathrm{CuSO}_{4}$, which removed excess $\mathrm{DAB}$ as its copper complex, ${ }^{31}$ thus reducing time-consuming chromatographic separations. The ${ }^{1} \mathrm{H}$ and ${ }^{13} \mathrm{C}$ NMR spectra in $\mathrm{CDCl}_{3}$ showed the presence of both the ribofuranose and benzimidazole units. The proton spectrum had the expected benzimidazole peaks at 7.90-7.94 $(\mathrm{H}-4,7)$ and 7.23-7.27 ppm $(\mathrm{H}-5,6)$. In the carbon spectrum the signals for benzamidazole unit were similar to those reported for the pyranosyl analogues $\mathbf{6}^{8}$ There were two distinct peaks at $151.3 \mathrm{ppm}$ and $123.2 \mathrm{ppm}$ for C-2 and C-5/6 respectively, with the other carbons giving broad signals. This effect has been reported previously for imidazoles and benzimidazoles, ${ }^{8,32}$ and is attributed to rapid proton exchange between $\mathrm{N}-1$ and $\mathrm{N}-3$. Debenzoylation using triethylamine/methanol yielded the parent 2- $\beta$-D-ribofuranosylbenzimidazole (22) $(91 \%)$. The overall yield from the oxime 16 to the benzimidazole 22 was $82 \%$.

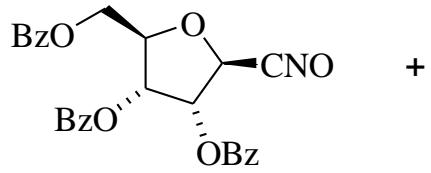

14<smiles>Nc1ccccc1N</smiles>

DAB

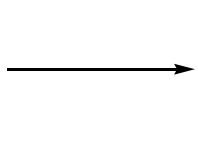<smiles>[R20]C[C@H]1O[C@@H](c2nc3ccccc3[nH]2)[C@H]([R20])[C@@H]1[R20]</smiles>

$21 \mathrm{R}=\mathrm{Bz}$

$22 \mathrm{R}=\mathrm{H}$

\section{Scheme 4}

In conclusion, these results also show that nitrile oxide addition chemistry can provide an effective alternative to current synthetic routes to furanosylbenzazoles. For example, 2-( $\beta$-Dribofuranosyl)benzimidazole can be prepared in four steps from the corresponding commercially-available cyanide in $58 \%$ overall yield. The same approach should also be applicable for the synthesis of 2-furanosylbenzothiazoles. An improved procedure for the conversion of furanosyl cyanides into furanosyl carbaldoximes has also been established.

\section{Experimental Section}

General. Melting points were measured on a Gallenkamp capillary apparatus and are uncorrected. Optical rotations were measured at $21{ }^{\circ} \mathrm{C}$ on an Optical Activity Polaar 20 polarimeter using $2 \mathrm{~mL}$ of filtered solution. The ${ }^{1} \mathrm{H}$ and ${ }^{13} \mathrm{C}$ NMR spectra were recorded with 
Brucker AX250 or Brucker avance spectrometers on solutions in $\mathrm{CDCl}_{3}$ (unless otherwise stated) with $\mathrm{Me}_{4} \mathrm{Si}$ as internal standard. Positive-ion $\mathrm{FAB}$ and high resolution mass spectra were obtained on a Kratos MS50TC instrument using either glycerol or thioglycerol matrices. Merck aluminium-backed plates coated with Kieselgel $\mathrm{GF}_{254}(0.2 \mathrm{~mm})$ were used for analytical TLC;

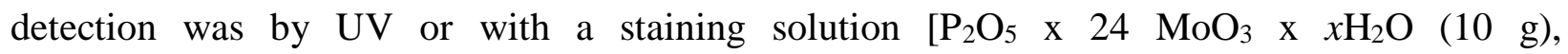
$\left(\mathrm{NH}_{4}\right)_{2} \mathrm{Ce}\left(\mathrm{NO}_{3}\right)_{6}(5 \mathrm{~g}), \mathrm{H}_{2} \mathrm{O}(450 \mathrm{~mL})$, and $\left.\mathrm{H}_{2} \mathrm{SO}_{4}(50 \mathrm{~mL})\right]$ and heat. Dry flash chromatography was carried out using Kieselgel $\mathrm{GF}_{254}$ and eluted under water pump vacuum. 2,3,5-Tri-Obenzoyl- $\beta$-D-ribofuranosyl acetate was purchased from Aldrich and used without further purification.

2,3,5-Tri- $\boldsymbol{O}$-benzoyl- $\boldsymbol{\beta}$-D-ribofuranosyl cyanide $(\mathbf{9}){ }^{23}$ To a stirred solution of 2,3,5-tri- $O$ benzoyl- $\beta$-D-ribofuranosyl acetate $(450 \mathrm{mg}, 1 \mathrm{mmol})$, trimethylsilyl cyanide $(0.5 \mathrm{~mL}, 4 \mathrm{mmol})$ and dry acetonitrile $(15 \mathrm{~mL})$ a few drops $(0.2 \mathrm{~mL})$ of $\mathrm{BF}_{3} . \mathrm{Et}_{2} \mathrm{O}$ were added. The reaction mixture was stirred under argon at room temperature for 10 minutes. After quenching with aq. $\mathrm{NaHCO}_{3}$ $(10 \mathrm{~mL})$, the mixture extracted with $\mathrm{Et}_{2} \mathrm{O}(3 \times 30 \mathrm{~mL})$ and the organic layers dried over $\mathrm{MgSO}_{4}$. The solvent was removed in vacuo and the resultant oil purified by chromatography (silica, $25 \%$ EtOAc in hexane) to afford the title compound as a white solid (360 mg, 86\%).

1,3-Diphenyl-2-(2',3',5'-tri- $\boldsymbol{O}$-benzoyl- $\boldsymbol{\beta}$-D-ribofuranosyl)imidazoline (10). Raney nickel (2 g) was added to a vigourously stirred solution of pyridine $(8 \mathrm{~mL})$, glacial acetic acid $(6 \mathrm{~mL})$ and water $(6 \mathrm{~mL}) . \mathrm{NaH}_{2} \mathrm{PO}_{2} \cdot \mathrm{H}_{2} \mathrm{O}(1 \mathrm{~g})$ was then added, along with 1,2-dianilinoethane (550 mg, 2.6 $\mathrm{mmol}$ ) and the D-ribose-derived cyanide $9(550 \mathrm{mg}, 2.5 \mathrm{mmol})$. After stirring for 16 hour, the resulting mixture was filtered through a pad of celite and the filter cake washed thoroughly with $\mathrm{CH}_{2} \mathrm{Cl}_{2}$. The filtrate was washed with water $(\sim 200 \mathrm{~mL})$, extracted with $\mathrm{CH}_{2} \mathrm{Cl}_{2}(2 \times 50 \mathrm{~mL})$ and the combined organic layers were dried over $\mathrm{MgSO}_{4}$. The solvent was co-evaporated with water (to remove residual pyridine) to yield a gum. The gum was dissolved in $\mathrm{CH}_{2} \mathrm{Cl}_{2}(5 \mathrm{~mL})$, acetic anhydride $(4.72 \mathrm{~mL})$ and triethylamine $(8.3 \mathrm{~mL})$ and the mixture stirred for 16 hours. The mixture was diluted with $\mathrm{CH}_{2} \mathrm{Cl}_{2}(20 \mathrm{~mL})$ and stirred with water $(20 \mathrm{~mL})$ for 20 minutes before extracting with $\mathrm{CH}_{2} \mathrm{Cl}_{2}$ (2 $\left.\mathrm{x} 10 \mathrm{~mL}\right)$. The combined organic layers were washed with aq. $\mathrm{NaHCO}_{3}(20 \mathrm{~mL})$ and dried over $\mathrm{MgSO}_{4}$. Dry-flash chromatography (silica, hexane/Et $2 \mathrm{O}$ gradient elution) afforded the product as a colourless oil, which solidified on addition of methanol (295 mg, 59\%). $[\alpha]_{\mathrm{D}}{ }^{20} 10\left(\mathrm{c}=0.1, \mathrm{CHCl}_{3}\right)\left(\mathrm{lit}^{33}[\alpha]_{\mathrm{D}}{ }^{23} 11.2\left(\mathrm{c}=0.1, \mathrm{CHCl}_{3}\right) ;{ }^{1} \mathrm{H}\right.$ NMR (360 MHz, $\left.\mathrm{CDCl}_{3}\right): \delta_{\mathrm{H}} 3.62-3.77\left(2 \mathrm{H}, \mathrm{m}, \mathrm{NCH}_{2}\right), 3.81-3.96\left(2 \mathrm{H}, \mathrm{m}, \mathrm{NCH}_{2}\right), 4.48(1 \mathrm{H}$, dd, $\left.{ }^{3} J_{5 \mathrm{a}-4} 4.7 \mathrm{~Hz},{ }^{2} J_{5 \mathrm{a}-5 \mathrm{~b}} 11.6 \mathrm{~Hz}, \mathrm{H}-5 \mathrm{a}\right), 4.57-4.61(1 \mathrm{H}, \mathrm{m}, \mathrm{H}-4), 4.66\left(1 \mathrm{H}, \mathrm{dd},{ }^{3} J_{5 \mathrm{~b}-4} 3.2 \mathrm{~Hz},{ }^{2} J_{5 \mathrm{~b}-}\right.$ 5a $11.6 \mathrm{~Hz}, \mathrm{H}-5 \mathrm{~b}), 4.92\left(1 \mathrm{H}, \mathrm{d},{ }^{3} J_{1-2} 5.4 \mathrm{~Hz}, \mathrm{H}-1\right), 5.61\left(1 \mathrm{H}, \mathrm{dd},{ }^{3} J_{3-4} 5.8 \mathrm{~Hz},{ }^{3} J_{3-2} 5.7 \mathrm{~Hz}, \mathrm{H}-3\right)$, $5.81\left(1 \mathrm{H}, \mathrm{dd},{ }^{3} J_{2-3} 5.7 \mathrm{~Hz},{ }^{3} J_{2-1} 5.4 \mathrm{~Hz}, \mathrm{H}-2\right), 5.97(1 \mathrm{H}, \mathrm{s}, \mathrm{CHN}), 6.79-6.97(4 \mathrm{H}, \mathrm{m}, \mathrm{ArH})$, 7.26-7.68 (15H, m, ArH), 7.82-8.06 (6H, m, ArH); $\left.{ }^{13} \mathrm{C} \mathrm{NMR} \mathrm{(93} \mathrm{MHz}, \mathrm{CDCl}_{3}\right): \delta_{\mathrm{C}} 48.0$ $\left(\mathrm{NCH}_{2}\right), 48.4\left(\mathrm{NCH}_{2}\right), 65.3(\mathrm{C}-5), 73.4,73.8,74.4$, (C-2, C-3, C-4), $80.6(\mathrm{C}-1), 84.2(\mathrm{CHN})$, 114.2, 114.6, 119.1, 128.5, 130.85 (ArCH), 134.1, 134.4, 134.5 (ArC), 166.5, 166.6, $167.2(3 \mathrm{x}$ COPh); MS (ES): $m / z, 483\left(\mathrm{MH}^{+}\right)$. 
2,5-Anhydro-3,4,6-tri- $\boldsymbol{O}$-benzoyl- $\boldsymbol{\beta}$-D-allose semicarbazone (12). Raney nickel (3.75 g) was added to a vigourously stirred solution of pyridine $(10 \mathrm{~mL})$, glacial acetic acid $(9 \mathrm{~mL})$ and water $(5 \mathrm{~mL}) . \mathrm{NaH}_{2} \mathrm{PO}_{2} \cdot \mathrm{H}_{2} \mathrm{O}(1.85 \mathrm{~g})$ was added, followed by semicarbazide hydrochloride $(550 \mathrm{mg})$ and $\mathrm{KOH}(285 \mathrm{mg})$ in water $(5 \mathrm{~mL})$ and the D-ribose-derived cyanide 9 (1.05 g, $2.41 \mathrm{mmol})$ in pyridine $(5 \mathrm{~mL})$. The reaction was heated to $40{ }^{\circ} \mathrm{C}$ for 4 hours. The resultant mixture was filtered through a pad of celite and the filter cake was washed thoroughly with $\mathrm{CH}_{2} \mathrm{Cl}_{2}$. The filtrate was washed with water $(\sim 200 \mathrm{~mL})$, extracted with $\mathrm{CH}_{2} \mathrm{Cl}_{2}(2 \times 50 \mathrm{~mL})$ and the combined organic layers were dried over $\mathrm{MgSO}_{4}$. The solvent was co-evaporated with water (to remove residual pyridine) to yield a gum. The mixture was diluted with $\mathrm{CH}_{2} \mathrm{Cl}_{2}(50 \mathrm{~mL})$ and washed with $1 \mathrm{M}$ $\mathrm{HCl}(2 \times 30 \mathrm{~mL}), \mathrm{NaHCO}_{3}(2 \times 30 \mathrm{~mL})$ and dried over $\mathrm{MgSO}_{4}$. Removal of the solvent in vacuo afforded crude semicarbazone 12 as a brown foam $(1.09 \mathrm{~g}, 85 \%) .{ }^{1} \mathrm{H}$ NMR $\left(250 \mathrm{MHz}, \mathrm{CDCl}_{3}\right)$ : $\delta_{\mathrm{H}} 4.43\left(1 \mathrm{H}, \mathrm{dd},{ }^{3} J_{5 \mathrm{a}-4} 3.6 \mathrm{~Hz},{ }^{2} J_{5 \mathrm{a}-5 \mathrm{~b}} 11.4 \mathrm{~Hz}, \mathrm{H}-5 \mathrm{a}\right), 4.51-4.64(2 \mathrm{H}, \mathrm{m}, \mathrm{H}-4, \mathrm{H}-5 \mathrm{~b}), 4.76(1 \mathrm{H}$, dd, $\left.{ }^{3} J_{1-2} 5.7 \mathrm{~Hz},{ }^{3} J_{1-1}, 4.8 \mathrm{~Hz}, \mathrm{H}-1\right), 5.69\left(1 \mathrm{H}, \mathrm{dd},{ }^{3} J_{3-2} 5.2 \mathrm{~Hz},{ }^{3} J_{3-4} 4.7 \mathrm{~Hz}, \mathrm{H}-3\right), 5.87(1 \mathrm{H}, \mathrm{dd}$, $\left.{ }^{3} J_{2-1} 5.7 \mathrm{~Hz},{ }^{3} J_{2-3} 5.2 \mathrm{~Hz}, \mathrm{H}-2\right), 7.13\left(1 \mathrm{H}, \mathrm{d},{ }^{3} J_{1^{\prime}-1} 4.8 \mathrm{~Hz}, H \mathrm{C}=\mathrm{NNHCONH}_{2}\right), 7.22-7.49(9 \mathrm{H}, \mathrm{m}$, $\mathrm{ArH}), 7.82-8.03(6 \mathrm{H}, \mathrm{m}, \mathrm{ArH}), 9.85(1 \mathrm{H}, \mathrm{brs}, \mathrm{NH}) ;{ }^{13} \mathrm{C} \mathrm{NMR}\left(63 \mathrm{MHz}, \mathrm{CDCl}_{3}\right): \delta_{\mathrm{C}} 63.8(\mathrm{C}-5)$, 67.7, 72.6, 72.8, (C-2, C-3, C-4,) 79.9 (C-1), 128.2, 128.3, 128.8, 129.2, 129.5 (ArCH), 133.1, 133.3, 133.6 (ArC), $138.6\left(\mathrm{HC}=\mathrm{NNHCONH}_{2}\right), 157.4\left(\mathrm{HC}=\mathrm{NNHCONH}_{2}\right), 165.1,165.2,166.0(3$ x $C \mathrm{OPh}) ; \mathrm{MS}(\mathrm{ES}): \mathrm{m} / z, 532\left(\mathrm{MH}^{+}\right)$.

2,5-Anhydro-3,4,6-tri- $\boldsymbol{O}$-benzoyl- $\boldsymbol{\beta}$-D-allose oxime (16). This compound was prepared by two methods:

Method A. Tosylic acid (212 mg, $1.1 \mathrm{mmol}$ ) was added to a solution of the imidazoline $\mathbf{1 0}$ (220 $\mathrm{mg}, 0.45 \mathrm{mmol})$ in $\mathrm{CH}_{2} \mathrm{Cl}_{2}(4.5 \mathrm{~mL})$, and the mixture stirred at room temperature under nitrogen for 45 minutes. The resultant mixture was filtered and the filter cake washed with $\mathrm{CH}_{2} \mathrm{Cl}_{2}$, before concentrating the filtrate in vacuo (the water bath temperature did not exceed $30{ }^{\circ} \mathrm{C}$ ). The residue was dissolved in ethanol $(2.5 \mathrm{~mL})$ and pyridine $(2.25 \mathrm{~mL})$, hydroxylamine hydrochloride (160 mg) was added, and the mixture heated to $95{ }^{\circ} \mathrm{C}$ under reflux for 2.5 hours. On cooling, the reaction mixture was diluted with $\mathrm{CH}_{2} \mathrm{Cl}_{2}(50 \mathrm{~mL})$ and washed with aq. $\mathrm{NHCO}_{3}(50 \mathrm{~mL})$, water $(50 \mathrm{~mL})$ and $1 \mathrm{M} \mathrm{HCl}(50 \mathrm{~mL})$, and the organic layer dried over $\mathrm{MgSO}_{4}$. Dry-flash chromatography ( silica, hexane/Et ${ }_{2} \mathrm{O}$ gradient elution) afforded the title compound as a colourless oil (100 mg, 45\%).

Method B. Hydroxylamine hydrochloride $(278 \mathrm{mg})$ was added to a solution of the semicarbazone $12(300 \mathrm{mg}, 0.6 \mathrm{mmol})$ in acetonitrile $(12.5 \mathrm{~mL})$ and pyridine $(4.2 \mathrm{~mL})$, and the resulting mixture was stirred at room temperature under argon for 16 hours. The mixture was diluted with ethyl acetate $(30 \mathrm{~mL})$ and washed with $1 \mathrm{M} \mathrm{HCl}(3 \times 30 \mathrm{~mL})$, aq. $\mathrm{NaHCO}_{3}(3 \times 30$ $\mathrm{mL})$ and brine $(30 \mathrm{~mL})$, before drying the organic layer over $\mathrm{MgSO}_{4}$. Wet-flash chromatography (silica, 25\% ethyl acetate in hexane) afforded the title compound as a colourless oil (236 mg, $81 \%)$.

$[\alpha]_{\mathrm{D}}{ }^{20} 14(\mathrm{c}=0.2, \mathrm{MeOH})\left(\right.$ lit. $\left.^{2}[\alpha]_{\mathrm{D}}{ }^{23} 12.9(\mathrm{c}=0.2, \mathrm{MeOH})\right) ;{ }^{1} \mathrm{H}$ NMR $\left(360 \mathrm{MHz}, \mathrm{CDCl}_{3}\right): \delta_{\mathrm{H}}$ $4.61\left(1 \mathrm{H}, \mathrm{dd},{ }^{3} J_{5 \mathrm{a}-4} 4.3 \mathrm{~Hz},{ }^{2} J_{5 \mathrm{a}-5 \mathrm{~b}} 11.7 \mathrm{~Hz}, \mathrm{H}-5 \mathrm{a}\right), 4.66-4.71(\mathrm{~m}, 1 \mathrm{H}, \mathrm{H}-4), 4.77\left(1 \mathrm{H}, \mathrm{dd},{ }^{3} J_{5 \mathrm{~b}-4}\right.$ $\left.3.2 \mathrm{~Hz},{ }^{2} J_{5 \mathrm{~b}-5 \mathrm{a}} 11.7 \mathrm{~Hz}, \mathrm{H}-5 \mathrm{~b}\right), 4.95\left(1 \mathrm{H}, \mathrm{dd},{ }^{3} J_{1-2} 5.5 \mathrm{~Hz},{ }^{3} J_{1-\mathrm{CH}=\mathrm{N}} 5.3 \mathrm{~Hz}, \mathrm{H}-1(E)\right), 5.53$ (1H, dd, 
$\left.{ }^{3} J_{1-\mathrm{CH}=\mathrm{N}} 5.0 \mathrm{~Hz},{ }^{3} J_{1-2} 4.7 \mathrm{~Hz}, \mathrm{H}-1(Z)\right), 5.75\left(1 \mathrm{H},{ }^{3} J_{3-2} 5.5 \mathrm{~Hz},{ }^{3} J_{3-4} 5.2 \mathrm{~Hz}, \mathrm{H}-3(Z)\right), 5.80-5.84(2 \mathrm{H}$, m, H-3(E), H-2(E)), $5.92\left(1 \mathrm{H}, \mathrm{dd},{ }^{3} J_{2-1} 4.7 \mathrm{~Hz},{ }^{3} J_{2-3} 5.2 \mathrm{~Hz}, \mathrm{H}-2(Z)\right), 6.99\left(1 \mathrm{H}, \mathrm{d},{ }^{3} J_{\mathrm{CH}=\mathrm{N}-1} 5.0 \mathrm{~Hz}\right.$, $H \mathrm{C}=\mathrm{NOH}(Z)), 7.31-8.22(16 \mathrm{H}, \mathrm{m}, H \mathrm{C}=\mathrm{NOH}, \mathrm{ArH}), 8.88(1 \mathrm{H}, \mathrm{brs}, \mathrm{OH}) ;{ }^{13} \mathrm{C} \mathrm{NMR}(93 \mathrm{MHz}$, $\left.\mathrm{CDCl}_{3}\right): \delta_{\mathrm{C}} 64.9(\mathrm{C}-5(Z)), 65.2(\mathrm{C}-5(E)), 73.4,73.6,74.6,75.1,78.5,79.6$, (C-2, C-3, C-4 (E and $Z)$ ), $80.2(\mathrm{C}-1(Z)), 80.4(\mathrm{C}-1(E)), 129.5,129.6,129.9,130.1,130.4,130.5,130.8,130.9$, 131.2 (ArCH), 134.4, 134.6, $134.7(\mathrm{ArC}), 148.8(\mathrm{C}=\mathrm{N}), 166.3,166.4,166.5,167.4(6 \times C \mathrm{OPh})$; MS (ES): $m / z, 490\left(\mathrm{MH}^{+}\right)$.

3,4-Di(2',3',5'-tri- $\boldsymbol{O}$-benzoyl- $\beta$-D-ribofuranosyl)-1,2,5-oxadiazole-2-oxide (17). A stirred mixture of ribose derived oxime $16(150 \mathrm{mg}, 0.3 \mathrm{mmol}), N$-chlorosuccinimide $(41 \mathrm{mg}, 0.30$ mmol), pyridine $(0.01 \mathrm{~mL})$ and chloroform $(2.5 \mathrm{~mL})$ was heated to $40{ }^{\circ} \mathrm{C}$ under nitrogen for 45 minutes. On cooling, triethylamine $(0.3 \mathrm{~mL})$ was added and the mixture stirred for 1 hour. The solution was diluted with $\mathrm{CH}_{2} \mathrm{Cl}_{2}(40 \mathrm{~mL}), 1 \mathrm{M} \mathrm{HCl}(40 \mathrm{~mL})$ and dried over $\mathrm{MgSO}_{4}$. Dry-flash chromatography (silica, hexane/ $\mathrm{Et}_{2} \mathrm{O}$ gradient elution) afforded the title compound as a colourless gum $(107 \mathrm{mg}, 72 \%)$. $[\alpha]_{\mathrm{D}}{ }^{20}-7.4\left(\mathrm{c}=5.65, \mathrm{CHCl}_{3}\right) ;{ }^{1} \mathrm{H} \mathrm{NMR}\left(250 \mathrm{MHz}, \mathrm{CDCl}_{3}\right): \delta_{\mathrm{H}}$ 4.45-4.63 (6H, m, H-5a, H-5b, H-5a', H-5b', H- 4, H-4'), 5.37 (1H, $\left.{ }^{3} J_{1-2} 5.4 \mathrm{~Hz}, \mathrm{H}-1\right), 5.46(2 \mathrm{H}$, d, $\left.{ }^{3} J_{1-2} 4.7 \mathrm{~Hz}, \mathrm{H}-1^{\prime}\right), 5.73-5.77\left(2 \mathrm{H}, \mathrm{m}, \mathrm{H}-3, \mathrm{H}-3{ }^{3}\right), 6.03\left(1 \mathrm{H}, \mathrm{dd},{ }^{3} J_{2-1} 5.4 \mathrm{~Hz},{ }^{3} J_{2-3} 6.0 \mathrm{~Hz}, \mathrm{H}-\right.$ 2), $6.15\left(1 \mathrm{H}, \mathrm{dd},{ }^{3} J_{2-1} 4.7 \mathrm{~Hz},{ }^{3} J_{2-3} 5.6 \mathrm{~Hz}, \mathrm{H}-2\right), 7.21-7.45(15 \mathrm{H}, \mathrm{m}, \operatorname{ArH}), 7.81-8.18(\mathrm{~m}, 12 \mathrm{H}$, $\mathrm{ArH}) ;{ }^{13} \mathrm{C}$ NMR $\left(63 \mathrm{MHz}, \mathrm{CDCl}_{3}\right): \delta_{\mathrm{C}} 63.6(\mathrm{C}-5), 63.8(\mathrm{C}-5$ ) $), 71.9,72.4,72.6,73.9,74.4,76.0$ (C-2, C-2’,C-3, C-3', C-4, C-4'), 80.6 (C-1), $80.3\left(\mathrm{C}^{\prime} \mathbf{1}^{\prime}\right)$ 112.6 (C=N), 128.9, 129.1, 129.2, 129.7, 129.8, 130.0, 130.2 ( $\mathrm{ArCH}), 133.7,134.1(\mathrm{ArC}), 155.0\left(\mathrm{C}=\mathrm{N}^{+}\right), 165.6,165.8,166.4$, 166.6 (6 x COPh); HRMS (FAB): Calcd. for $\mathrm{C}_{54} \mathrm{H}_{42} \mathrm{~N}_{2} \mathrm{O}_{16}:[\mathrm{M}+\mathrm{H}]$ 975.2613. Found: $\mathrm{m} / \mathrm{z}$ 975.2602 .

2-(2',3',5'-Tri- $\boldsymbol{O}$-benzoyl- $\beta$-D-ribofuranosyl)benzoxazole (18). A stirred mixture of D-ribosederived oxime $16(150 \mathrm{mg}, 0.30 \mathrm{mmol}), N$-chlorosuccinimide $(41 \mathrm{mg}, 0.30 \mathrm{mmol})$, pyridine $(0.01 \mathrm{~mL})$ and chloroform $(2.5 \mathrm{~mL})$ was heated to $40{ }^{\circ} \mathrm{C}$ under nitrogen for 45 minutes. The solvent was removed in vacuo before ethanol $(10 \mathrm{~mL})$ and 2-aminophenol $(85 \mathrm{mg}, 0.75 \mathrm{mmol})$ were added, and the mixture heated at reflux for 5 hours. On cooling, the solvent was removed in vacuo and $\mathrm{CH}_{2} \mathrm{Cl}_{2}$ added to precipitate out excess 2-aminophenol. After filtration, the solution was washed with $1 \mathrm{M} \mathrm{HCl}(20 \mathrm{~mL})$ and dried over $\mathrm{MgSO}_{4}$. Dry-flash chromatography (silica, hexane/ $\mathrm{Et}_{2} \mathrm{O}$ gradient elution) afforded the title compound as a colourless gum $(155 \mathrm{mg}, 92 \%)$. $[\alpha]_{\mathrm{D}}{ }^{20}-125\left(\mathrm{c}=2.9, \mathrm{CHCl}_{3}\right) ;{ }^{1} \mathrm{H}$ NMR $\left(360 \mathrm{MHz}, \mathrm{CDCl}_{3}\right): \delta_{\mathrm{H}} 4.66\left(1 \mathrm{H}, \mathrm{dd},{ }^{3} J_{5 \mathrm{a}-4} 3.0 \mathrm{~Hz},{ }^{2} J_{5 \mathrm{a}-5 \mathrm{~b}}\right.$ $11.5 \mathrm{~Hz}, \mathrm{H}-5 \mathrm{a}), 4.83-4.92(2 \mathrm{H}, \mathrm{m}, \mathrm{H}-4, \mathrm{H}-5 \mathrm{~b}), 5.62\left(1 \mathrm{H}, \mathrm{d},{ }^{3} J_{1-2} 4.6 \mathrm{~Hz}, \mathrm{H}-1\right), 6.11\left(1 \mathrm{H}, \mathrm{dd},{ }^{3} J_{3-4}\right.$ $\left.5.4 \mathrm{~Hz},{ }^{3} J_{3-2} 4.9 \mathrm{~Hz}, \mathrm{H}-3\right), 6.28\left(1 \mathrm{H}, \mathrm{dd},{ }^{3} J_{2-3} 4.9 \mathrm{~Hz},{ }^{3} J_{2-1} 4.6 \mathrm{~Hz}, \mathrm{H}-2\right), 7.30-7.41(10 \mathrm{H}, \mathrm{m}$, $\mathrm{ArH}), 7.53-7.58(3 \mathrm{H}, \mathrm{m}, \mathrm{ArH}), 7.72-7.74(1 \mathrm{H}, \mathrm{m}, \mathrm{ArH}), 7.98-8.12(5 \mathrm{H}, \mathrm{m}, \mathrm{ArH}) ;{ }^{13} \mathrm{C} \mathrm{NMR}(93$ $\left.\mathrm{MHz}, \mathrm{CDCl}_{3}\right): \delta_{\mathrm{C}} 61.4(\mathrm{C}-5), 64.6,73.6,75.7,(\mathrm{C}-2, \mathrm{C}-3, \mathrm{C}-4), 81.6$ (C-1), 112.0 (C-7), 121.7 (ArC-4), 125.7 (ArC-6), 126.9 (ArC-5), 129.4, 129.5, 129.8, 129.9, 130.6, 130.9 (ArCH), 131.0, 134.2, 134.6 (ArC), 141.7 (ArC-3a), 152.0 (ArC-7a), 162.5 (ArC-2), 166.2, 166.3, 167.2 (3 x COPh); MS (FAB): $m / z 564\left(\mathrm{MH}^{+}\right)$; HRMS (FAB): Calcd. for $\mathrm{C}_{33} \mathrm{H}_{25} \mathrm{NO}_{8}$ : [M+H] 564.1658. Found: $m / z 564.1666$. 
2-(D-Ribofuranosyl)benzoxazole (19). A solution of 2-(2,3,5-tri- $O$-benzoyl- $\beta$-Dribofuranosyl)benzoxazole $(169 \mathrm{mg}, 0.3 \mathrm{mmol})$ in methanol $(8 \mathrm{~mL})$ was stirred at room temperature. Freshly prepared $1 \mathrm{M} \mathrm{NaOMe}(7 \mathrm{~mL})$ solution was added, and the reaction stirred for 16 hours. Amberlite $120\left(\mathrm{H}^{+}\right)$resin was added in portions until the solution was neutral to $\mathrm{pH}$ paper. After filtration the resulting solution was concentrated in vacuo to afford a residue. Following wet-flash chromatography (silica, $10 \%$ methanol in ethyl acetate), 2-( $\beta$-Dribofuranosyl)benzoxazole was obtained as an inseparable mixture of anomers $(\beta: \alpha, 62: 38)$ (colourless foam, $65 \mathrm{mg}, 87 \%)$. ${ }^{1} \mathrm{H}$ NMR $\left(360 \mathrm{MHz}, \mathrm{D}_{2} \mathrm{O}\right)$ : furanose signals: $\delta_{\mathrm{H}} \beta$-anomer: 3.74 $\left(1 \mathrm{H}, \mathrm{dd},{ }^{3} J_{5 \mathrm{a}-4} 4.1 \mathrm{~Hz},{ }^{2} J_{5 \mathrm{a}-5 \mathrm{~b}} 12.7 \mathrm{~Hz}, \mathrm{H}-5 \mathrm{a}\right), 3.89\left(1 \mathrm{H}, \mathrm{dd},{ }^{3} J_{5 \mathrm{~b}-4} 2.9 \mathrm{~Hz},{ }^{2} J_{5 \mathrm{~b}-5 \mathrm{a}} 12.7 \mathrm{~Hz}, \mathrm{H}-5 \mathrm{~b}\right)$, $4.07(1 \mathrm{H}, \mathrm{m}, \mathrm{H}-4), 4.14(1 \mathrm{H}, \mathrm{m}, \mathrm{H}-3), 4.34\left(1 \mathrm{H}, \mathrm{dd},{ }^{3} J_{2-3} 4.6 \mathrm{~Hz},{ }^{3} J_{2-1} 3.3 \mathrm{~Hz}, \mathrm{H}-2\right), 4.47(1 \mathrm{H}, \mathrm{d}$, $\left.{ }^{3} J_{1-2} 3.3 \mathrm{~Hz}, \mathrm{H}-1\right)$; $\alpha$-anomer: $3.71\left(1 \mathrm{H}, \mathrm{dd},{ }^{3} J_{5 \mathrm{a}-4} 5.3 \mathrm{~Hz},{ }^{2} J_{5 \mathrm{a}-5 \mathrm{~b}} 12.6 \mathrm{~Hz}, \mathrm{H}-5 \mathrm{a}\right), 3.82(1 \mathrm{H}$, dd, $\left.{ }^{3} J_{5 \mathrm{~b}-4} 3.4 \mathrm{~Hz},{ }^{2} J_{5 \mathrm{~b}-5 \mathrm{a}} 12.6 \mathrm{~Hz}, \mathrm{H}-5 \mathrm{~b}\right), 4.14(1 \mathrm{H}, \mathrm{m}, \mathrm{H}-4), 4.26\left(1 \mathrm{H}, \mathrm{dd},{ }^{3} J_{3-2} 5.2 \mathrm{~Hz},{ }^{3} J_{3-4} 5.2 \mathrm{~Hz}\right.$, H-3), $4.53\left(1 \mathrm{H}, \mathrm{dd},{ }^{3} J_{2-1} 5.3 \mathrm{~Hz},{ }^{3} J_{2-3} 5.2 \mathrm{~Hz}, \mathrm{H}-2\right), 5.08\left(1 \mathrm{H}, \mathrm{d},{ }^{3} J_{1-2} 5.3 \mathrm{~Hz}, \mathrm{H}-1\right)$; aromatic signals: $\delta_{\mathrm{H}} 6.92-6.96(\mathrm{~m}, 2 \mathrm{H}, \operatorname{ArH}), 7.12-7.14(\mathrm{~m}, 1 \mathrm{H}, \operatorname{ArH}), 7.38-7.44(\mathrm{~m}, 3 \mathrm{H}, \operatorname{ArH})$, 7.59-7.67 (m, 2H, ArH); ${ }^{13} \mathrm{C}$ NMR (63 MHz, $\left.\mathrm{D}_{2} \mathrm{O}\right): \delta_{\mathrm{C}} 60.6,61.8$ (C-5 $\left.\alpha, \mathrm{C}-5 \beta\right), 70.5,71.5,74.8$,

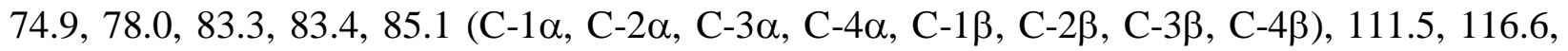
$119.8,120.9,123.4,125.5,126.5,128.3(\mathrm{ArCH}), 139.6,149.3,150.8(\mathrm{ArC}), 164.1(\mathrm{C}=\mathrm{N}) ; \mathrm{m} / z$ (FAB) $252\left(\mathrm{MH}^{+}\right)$; HRMS (FAB): Calcd. for $\mathrm{C}_{12} \mathrm{H}_{14} \mathrm{NO}_{5}$ : [M+H] 252.08720. Found: $\mathrm{m} / z$ 252.08755 .

2-(2',3',5'-Tri- $\boldsymbol{O}$-benzoyl- $\boldsymbol{\beta}$-D-ribofuranosyl)benzimidazole (21). A stirred mixture of Dribose-derived oxime $16(150 \mathrm{mg}, 0.30 \mathrm{mmol}), N$-chlorosuccinimide (41 mg, $0.30 \mathrm{mmol})$, pyridine $(0.01 \mathrm{~mL})$ and chloroform $(2.5 \mathrm{~mL})$ was heated to $40{ }^{\circ} \mathrm{C}$ under nitrogen for 45 minutes. The solvent was removed in vacuo before adding ethanol $(10 \mathrm{~mL})$ and $o$-phenylenediamine $(85$ $\mathrm{mg}, 0.75 \mathrm{mmol}$ ) and the mixture was heated to reflux for 5 hours. On cooling, the reaction mixture was diluted with $\mathrm{CH}_{2} \mathrm{Cl}_{2}(50 \mathrm{~mL})$ and washed with $4 \%$ aq. $\mathrm{CuSO}_{4}$ solution $(50 \mathrm{~mL})$, the aqueous layer was further extracted with $\mathrm{CH}_{2} \mathrm{Cl}_{2}(2 \times 50 \mathrm{~mL})$, and the combined organic layers dried $\left(\mathrm{MgSO}_{4}\right)$. Dry-flash chromatography (silica, hexane/Et $2 \mathrm{O}$ gradient elution) afforded the title compound as a colourless gum $(152 \mathrm{mg}, 90 \%) . \quad[\alpha]_{\mathrm{D}}{ }^{20}-106\left(\mathrm{c}=3.65, \mathrm{CHCl}_{3}\right) ;{ }^{1} \mathrm{H} \mathrm{NMR}$ $\left(360 \mathrm{MHz}, \mathrm{CDCl}_{3}\right): \delta_{\mathrm{H}} 4.78-4.88(3 \mathrm{H}, \mathrm{m}, \mathrm{H}-5 \mathrm{a}, \mathrm{H}-4, \mathrm{H}-5 \mathrm{~b}), 5.72\left(1 \mathrm{H}, \mathrm{d},{ }^{3} J_{1-2} 4.4 \mathrm{~Hz}, \mathrm{H}-1\right), 5.80$ $\left(1 \mathrm{H}, \mathrm{dd},{ }^{3} J_{3-4} 5.3 \mathrm{~Hz},{ }^{3} J_{3-2} 4.8 \mathrm{~Hz}, \mathrm{H}-3\right), 6.09\left(1 \mathrm{H}, \mathrm{dd},{ }^{3} J_{2-3} 4.8 \mathrm{~Hz},{ }^{3} J_{2-1} 4.4 \mathrm{~Hz}, \mathrm{H}-2\right), 7.23-7.27$ $(2 \mathrm{H}, \mathrm{m}, \mathrm{ArH}), 7.33-7.59(11 \mathrm{H}, \mathrm{m}, \mathrm{ArH}), 7.90-7.94(2 \mathrm{H}, \mathrm{m}, \mathrm{ArH}), 8.03-8.08(4 \mathrm{H}, \mathrm{m}, \mathrm{ArH}) ;{ }^{13} \mathrm{C}$ NMR (93 MHz, $\mathrm{CDCl}_{3}$ ): $\delta_{\mathrm{C}} 64.6$ (C-5), 72.6, 76.5, 78.9 (C-2, C-3, C-4), 80.9 (C-1), 114.2-118.7 (bs, C-4, C-7), 123.2 (C-5, C-6), 128.9, 129.0, 129.2, 129.3, 129.6, 130.2 (ArCH), 130.3, 133.9 (ArC), 151.3 (ArC-2), 165.7, 167.2 (3 x COPh); MS (FAB): $m / z 563\left(\mathrm{MH}^{+}\right)$; HRMS (FAB): Calcd. for $\mathrm{C}_{33} \mathrm{H}_{26} \mathrm{~N}_{2} \mathrm{O}_{7}$ : $[\mathrm{M}+\mathrm{H}]$ 563.1818. Found: $m / z$ 563.1811.

2-( $\beta$-D-Ribofuranosyl)benzimidazole (22). A mixture of the tri- $O$-benzoyl- $\beta$-Dribofuranosyl)benzimidazole $(\mathbf{2 1})(90 \mathrm{mg}, 0.16 \mathrm{mmol})$, methanol $(5 \mathrm{~mL})$ and triethylamine $(0.8$ $\mathrm{mL}, 5.7 \mathrm{mmol}$ ) was heated at $50^{\circ} \mathrm{C}$ for 4 days. On cooling, the product was purified by wet-flash fschromatography (silica, $10 \% \mathrm{MeOH}$ in EtOAc) to afford the title compound as a colourless foam (43 mg, 91\%). ${ }^{1} \mathrm{H}$ NMR (250 MHz, $\left.\mathrm{D}_{2} \mathrm{O}\right): \delta_{\mathrm{H}} 3.61\left(1 \mathrm{H}, \mathrm{dd},{ }^{3} J_{5 \mathrm{a}-4} 3.8 \mathrm{~Hz},{ }^{2} J_{5 \mathrm{a}-5 \mathrm{~b}} 12.3 \mathrm{~Hz}\right.$, 
H-5a), 3.76 (1H, dd, $\left.{ }^{3} J_{5 \mathrm{~b}-4} 2.0 \mathrm{~Hz},{ }^{2} J_{5 \mathrm{~b}-5 \mathrm{a}} 12.3 \mathrm{~Hz}, \mathrm{H}-5 \mathrm{~b}\right), 3.98-4.05$ (2H, m, H-3', H- 4'), 4.21 $\left(1 \mathrm{H}, \mathrm{dd},{ }^{3} J_{2-1} 5.3 \mathrm{~Hz},{ }^{3} J_{2-3} 4.4 \mathrm{~Hz}, \mathrm{H}-2\right), 4.92$ (1H, d, $\left.{ }^{3} J_{1-2} 5.3 \mathrm{~Hz}, \mathrm{H}-1\right), 7.07-7.10$ (2H, m, ArH), 7.35-7.41 (2H, m, ArH); ${ }^{13} \mathrm{C}$ NMR (63 MHz, $\left.\mathrm{D}_{2} \mathrm{O}\right): \delta_{\mathrm{C}} 61.7$ (C-5), 71.2, 75.7, 78.9, 84.7 (C-1, C-2, C-3, C-4), 115.3 (broad) (ArC-4, ArC-7), 123.2 (ArC-5, ArC-6), 152.9 (ArC-2); MS (FAB): $m / z 251\left(\mathrm{MH}^{+}\right)$; HRMS (FAB): Calcd. for $\mathrm{C}_{12} \mathrm{H}_{15} \mathrm{~N}_{2} \mathrm{O}_{4}:[\mathrm{M}+\mathrm{H}]$ 251.1032. Found: $m / z$ 251.1032.

\section{Acknowledgements}

We are grateful to the EPSRC for research and maintenance (I.A.S.S.) grants. We thank Dr Vincent Aucagne for helpful discussions.

\section{References}

1. For reviews and monographs of $C$-nucleoside chemistry see: (a) Shaban, M. A. E.; Nasr, A. Z. Adv. Heterocycl. Chem. 1997, 68, 223. (b) Shaban, M. A. E. Adv. Heterocycl. Chem. 1998, 70, 163. (c) Wellington, K. W.; Benner, S. A. Nuleosides, Nucleotides Nucleic Acids 2006, 25, 1309. (d) Levy, D. E. Organic Chemistry of Sugars; Levy, D. E.; Fuegedi, P. Eds.; Taylor \& Francis: Boca Raton, 2006, Ch. 7. (e) Stambasky, J.; Hocek, M.; Kocovsky, P. Chem. Rev. 2009, 109, 6279.

2. Albrecht, H. P.; Repke, D. B.; Moffat, J. G. J. Org. Chem. 1975, 40, 2143.

3. Kozikowski, A. P.; Goldstein, S. J. Org. Chem. 1983, 48, 1141.

4. Kozikowski. A. P.; Chen, X. M. J. Chem. Soc., Chem. Commun. 1987, 680.

5. Baraldi, P. G.; Bigoni, A.; Cacciari, B.; Caldari, C.; Manfredini, S.; Spalluto, G. Synthesis 1994, 1158.

6. For reviews and monographs of nitrile oxide-isoxazoline chemistry see: (a) Kozikowski, A. P. Acc. Chem. Res. 1984, 17, 410. (b) Jäger, V.; Müller, I.; Schohe, R.; Frey, M.; Ehrler, R.; Häfele, B.; Schröter, D. Lect. Heterocycl. Chem. 1985, 8, 79. (c) Baraldi, P. G.; Barco, A.; Benetti, G. P.; Pollini, P.; Simoni, D. Synthesis 1987, 857. (d) Curran, D. P. Adv. Cycloaddition 1988, 1, 129. (e) Baraldi, P. G.; Barco, A.; Benetti, S.; Pollini, G. P.; Simoni, D. Synthesis 1987, 857. (f) Kanemasa, S.; Tsuge, O. Heterocycles 1990, 30, 719. (g) Grünanger, P.; Vita-Finzi, P. In Isoxazoles: The Chemistry of Heterocyclic Compounds, Vol. 49, Part 1; Wiley: New York, 1991. (h) Jäger, V.; Müller, I.; Leibold, T.; Hein, M.; Schwarz, M.; Fengler, M.; Jaroskova, L.; Pätzel, M.; LeRoy, P.-V. Bull. Soc. Chim. Belg. 1994, 103, 491. (i) Torssell, K. B. G. Nitrile Oxides, Nitrones and Nitronates in Organic Synthesis; VCH Publishers, Weinheim, 1998. (j) Murugan, R. In Comprehensive Heterocyclic Chemistry II; Katritzky, A. R.; Rees, C. W.; Scriven, E. F. V. Eds.; Pergamon: Oxford, 1996; Chapter 3.03. (k) Paton, R. M. in Carbohydrate Mimics. Concepts and Methods; Chapleur, Y., Ed.; VCH Publishers, Weinheim, 1998, Chapter 3. (l) Giomi, D.; Cordero, F. M.; 
Machetti, F. In Comprehensive Heterocyclic Chemistry III; Katritzky, A. R.; Ramsden, C. A..; Scriven, E. F. V.; Taylor, R. J. K. Eds.; Pergamon: Oxford, 2008; Chapter 4.03. (m) Namboothiri, I. N. N.; Rastogi, N. Top. Heterocycl. Chem. 2008, 12, 1.

7. For a review see: Grassi, G.; Risitano, F. Targets Heterocycl. Systems 1997, 1, 141.

8. Smellie, I. A. S.; Fromm, A.; Fabbiani, F.; Oswald, I. D. H.; White, F. J.; Paton, R. M. Tetrahedron 2010, 66, 7155.

9. Holy, A. Curr. Pharm. Design 2003, 9, 2567.

10. Kumar, Curr. Med. Chem. 2004, 11, 2749.

11. (a) Mack, S. R.; Sabin, V. M.; Galvin, F. C. A. PCT Int. Appl. 2003, WO 2003011885 A1 2003213. CAN 138:137532 (b) Davenport, R. J.; Diaz, P.; Galvin, F. C. A.; Lloyd, S.; Mack, S. R.; Owens, R.; Sabin, V.; Wynn, J. Bioorg. Med. Chem. Lett. 2007, 17, 558.

12. Ogura, H.; Takahashi, H. J. Org. Chem. 1974, 39, 1374.

13. Guianvarc'h, D.; Benhida, R.; Fourrey, J. L. Tetrahedron Lett. 2001, 42, 647.

14. Guianvarc'h, D.; Fourrey, J. L.; Tran Huu Dau, M. E.; Guerineau, V.; Benhida, R. J. Org. Chem. 2002, 67, 3724.

15. Bobek, M.; Farkas, I. Coll. Czech. Chem. Commun. 1969, 34, 247.

16. El Khadem, H. S.; Kawai, J. Carbohydr. Res. 1986, 153, 271.

17. For a review see: Gallos, J. K.; Koumbis, A. E. Curr. Org. Chem. 2003, 7, 397.

18. (a) Grundmann, C.; Grünanger, P. The Nitrile Oxides; Springer-Verlag, Heidelberg, 1971. (b) Caramella, P.; Grünanger, P. in 1,3-Dipolar Cycloaddiiton Chemistry; Padwa, A. Ed.; Wiley, New York, 1984, Vol. 1, Chapter 3.

19. Mukaiyama, T.; Hoshino, T. J. Am. Chem. Soc. 1960, 82, 5339.

20. Dawson, I. M.; Johnson, T.; Paton, R. M.; Rennie, R. A. C. J. Chem. Soc., Chem. Commun. 1988, 1339.

21. (a) Takamoto, T.; Omi, H.; Matsuzaki, T.; Sudoh, R. Carbohydr. Res. 1978, 60, 97. (b) Sakakibara, T.; Takamoto, T.; Matsuzaki, T.; Omi, H.; Win Muang, U.; Sudoh, R. Carbohydr. Res. 1981, 95, 291.

22. Köll, P.; Kopf, J.; Brandenburg, H. Liebigs Ann. Chem. 1988, 685.

23. Morelli, C. F.; Manfredini, N.; Veronese, A. C. Tetrahedron 1999, 55, 10803.

24. Toth, M.; Somsak, L. Carbohydr. Res. 2003, 338, 1319.

25. (a) Baker, K. W. J.; Gibb, A.; March, A. R.; Paton, R. M. Tetrahedron Lett. 2001, 42, 4065.

(b) Baker, K. W. J.; March, A. R.; Parsons, S.; Paton, R. M.; Stewart, G. W. Tetrahedron 2002, 58, 8505.

26. Larsen, K. E.; Torssell, K. B. G. Tetrahedron 1984, 40, 2985.

27. Paton, R. M. In Comprehensive Heterocyclic Chemitry II; Katritzky, A. R.; Rees, C. W.; Scriven, E. F. V. Eds.; Pergamon: Oxford, 1996; Chapter 4.05 and references therein.

28. Gasco, A.; Boulton, A. J. Adv. Heterocycl. Chem. 1981, 29, 251.

29. Farkas, I.; Szabo, I.; Bognar, R. Carbohydr. Res. 1977, 56, 404.

30. Llinares, J.; Galy, J.-P.; Faure, R.J.; Elguero, J. Can. J. Chem. 1979, 57, 937.

31. Duff, E. J. J. Chem. Soc. A 1968, 434. 
32. Grimmet, M. R. In Comprehensive Heterocyclic Chemistry; Katritzky, A. R.; Rees, C. W.; Scriven, E. F. V., Eds.; Pergamon: Oxford, 1984, Chapter 4.06 and references therein.

33. Albrecht, H. P.; Repke, D. B.; Moffat, J. G. J. Org. Chem. 1975, 40, 2143. 